\title{
Empirical Evidence on the Value Relevance of Brand Values across Countries
}

\author{
Grazia Dicuonzo ${ }^{1}$, Andrea Perrone ${ }^{1}$, Vittorio Dell'Atti ${ }^{1}$ \\ ${ }^{1}$ Department of Economics, Management and Business Law, University of Bari Aldo Moro, Italy \\ Correspondence: Grazia Dicuonzo, Department of Economics, Management and Business Law, University of \\ Bari Aldo Moro, Italy.
}

Received: December 6, 2017

Accepted: January 16, $2018 \quad$ Online Published: January 26, 2018

doi:10.5539/ibr.v11n2p197

URL: https://doi.org/10.5539/ibr.v11n2p197

\begin{abstract}
Stock prices reflect firms-related information differently depending on the environmental and institutional context. However, previous empirical studies test mainly accounting data. Since intangible assets became a crucial element for business success and brands are considered critical for value creation, correlated disclosure is proven to be value relevant for investors. The majority of accounting standards do not allow to recognize internally generated intangible assets in the balance sheet and therefore more and more practitioners, both investors and analysts, use brand values provided by third independent parties, such as consulting firms. The purpose of this paper is to investigate whether and how brand-related information differs across countries testing the value relevance of brand values published in Brand Finance's Reports. This study aims to open a new stream of literature regarding the value relevance of non-accounting information across countries.
\end{abstract}

Keywords: brand valuation, cross-country, intangible assets, stock markets, value relevance

\section{Introduction}

Intangible assets represent one of determinants of firm value. In particular, companies pay more attention to the promotion of their brands since they consider them as a crucial asset for value creation (Madden, Fehle \& Fournier, 2006) and as dri vers of abnormal earnings creation (Beretta Zanoni \& Vernizzi, 2014). The importance of brands is also recognized by investors and financial analysts, which take into consideration brand values in their decision making-process. Empirical studies find a positive relationship between the value of these intangibles and firms' financial performance (Kerin \& Sethuraman, 1998). Brands can be also evaluated for other purposes, such as to take advantage of fiscal benefits or in the context of the firms' acquisitions to apply the purchase price allocation. However, the lack of guidelines and best practices often pushes practitioners to use values provided by consulting firms. Literature proves that brand values estimated and published by third independent parties are reflected on stock prices and returns (Barth, Clement, Foster \& Kasznik, 1998). The results reveal that non-accounting values provided by consulting firms (e.g. Interbrand, Brand Finance and BrandZ) are relevant to equity valuation of companies (Bagna, Dicuonzo, Perrone \& Dell'Atti, 2017). This is due to two main reasons: (1) the significant role brands take on in firm valuation (Barth \& Clinch, 1998) and (2) the denial by many accounting standards to recognize internally built intangible assets, as most of the brands are. Therefore, investors and practitioners use reports published by consulting firms to fulfil the need of brand-related information. Although the positive association between brand values and stock prices has been demonstrated, it is unquestionable that it could differ across countries. To improve the efficiency of financial markets and optimize the capital allocation, it is beneficial to know if and how information (both accounting and non-accounting) are reflected into stock prices in each market; namely, if an information is value relevant in a given financial market. While the different value relevance of accounting data across countries has been widely investigated, no study provides empirical evidence about this critical issue regarding brand values.

The aim of this study is to contribute to filling this research gap investigating whether and how the value relevance of brand values estimated by consulting firms differs across countries. The empirical analysis is based on a sample of 2,518 brand values, hand-collected from reports published by Brand Finance in the period 2008-2015, referable to 17 different countries. Through the use of traditional value relevance regression analysis, we expect to find a different significance of brand values coefficients in each market. Our hypothesis is that, given the presence of country-specific factors, brand values are differently reflected into stock prices. 
This paper presents both theoretical and practical contributions. It extends prior literature on capital market research providing empirical evidence on the different informative content of non-accounting data. Also, the results could help investors in their decision-making process, providing more tools to analyze the ability of stock prices to capture non-accounting information in different institutional context in order to make capital allocation more efficiently. However, this research represents a first step, which needs to be followed by the recognition of country-specific factors that produce the identified divergence.

The remainder of this paper is structured as follows. Section 2 presents a review of previous empirical studies and the hypothesis development. Section 3 describes the research method and the data used, while section 4 discusses results. Finally, section 5 details the conclusions and the limitations which affect the current study.

\section{Literature Review \& Hypothesis Development}

Prior literature provides many proofs of the value relevance of brand values. Barth et al. (1998) show that brand values provided by Financial World from 1991 to 1996 are reflected into stock prices and returns. Also, Barth and Clinch (1998) demonstrate that intangible assets of a sample of Australian firms are value relevant and identify brands as a relevant portion of them. Aaker and Jacobson (2001) find out the informative content of brand attitude, defined as a component of brand equity, and that its change influences financial performance. Kallapur and Kwan (2004) show that the first recognition of brands in a sample of UK firms has an impact on stock prices. They highlight this influence in the first 21 days after announcement by management, even if managers tend to overestimate brand values. Mizik and Jacobson (2008) identify relevance and energy as Y\&R Brand Asset Valuator's metrics which explain the informative content of brands. Examining the industry effect, Kirk, Ray and Wilson (2013) reveal that the association between brand values and stock prices depends on firm type. They find that this relationship is significant for consumers firms but not significant for industrial firms. Analyzing reports published by different consulting firms, Bagna et al. (2017) identify Brand Finance values as the most value relevant, compared to Interbrand and BrandZ values, due to the different evaluation methods used by each provider.

Although e vidence reveals a positive association between brand values and stock prices, a central issue is to understand whether this relationship differs across countries. Alford, Jones, Leftwich and Zmijewski (1993) analyze the difference in information content and timeliness of accounting earnings in 17 different countries due to the different accounting systems, using USA as benchmark. Results show a higher value relevance and timeliness for accounting earnings reported using local-GAAP in Australia, France, Netherlands and UK, compared to US firms adopting related accounting standards (i.e. US-GAAP); other countries' local-GAAP (e.g. Italian, Danish, Swedish and Singaporean) produce a lower value relevance and timeliness for accounting earnings then US firms. For other countries, findings are uncertain. Ali and Hwang (2000) test how four measures of value relevance of accounting data differ across countries, using a sample of US firms as benchmark. Arce and Mora (2002) pay attention to the accounting differences among European countries and how these have impact on the valuation of earnings and book value. Although results are not uni vocal, the authors conclude that the different accounting systems differently affect the information content of earnings and book value in European countries. Hellström (2006) studies the case of the value relevance in a transitional economy (i.e. Czech Republic), comparing it to a developed economy (i.e. Sweden). Using observation from both countries in the years from 1994 to 2001, the author identifies an improvement in the informative content of accounting variables. The results obtained by the regression analysis are confirmed by the author using the hedge portfolio methodology. Brown, He and Teitel (2006) test the association between the value relevance of earnings and conditional conservatism, using a sample of 20 different countries which differ for the level of accrual intensity. Findings show that "artifacts of legal environments that reduce managers' opportunistic behavior" such as conditional conservatism and shareholders' protection are complementary and have a positive effect on the value relevance of reported earnings. Finally, Camodeca, Almici and Renzi Brivio (2014) show that accounting data are differently reflected in stock prices in Italy and United Kingdom. The evidence reveals a higher value relevance in the Italian market, and in particular a different information content of NIBEI (Net Income Before Extraordinary Items) and OCF (Operating Cash Flows) in the two markets.

In summary, the literature provides strong evidence that accounting information is reflected into stock markets differently across countries due to diverse institutional context and environmental characteristics. However, no study investigates this cross-country difference in the value relevance of non-accounting data.

The purpose of this study is to verify whether the association between brand values provided by independent third parties and stock prices differs across country. On the one hand, previous works demonstrate that brand values published by consulting firms are taken into consideration by investors and therefore they are reflected in 
the stock prices (Barth et al., 1998; Bagna et al., 2017). On the other hand, other empirical analyses reveal that the value relevance of accounting data differs across countries due to environmental characteristics and institutional context (Ali \& Hwang, 2000; Arce \& Mora, 2002; Hellström, 2005).

Moving from these two streams of literature, we formulate the following hypothesis:

HP: The value relevance of brand values provided by independent third parties differs across countries.

\section{Research Method}

In order to investigate whether accounting variables are reflected into stock prices, previous studies use Ohlson's model (1995). Following this model, the authors regress market value on book value and net income over the sample. To verify our hypothesis we run a traditional value relevance regression analysis, considering brand values as "other information content". This approach has been firstly adopted by Barth et al. (1998) to test the informative content of brand values. Since we carry out a cross country analysis, we run a separate regression for each country to obtain the beta coefficients of brand values. The model is set up as follow:

$$
M V_{i, j}=\alpha+\beta_{B V} B V_{i, j}+\beta_{N I} N I_{i, j}+\beta_{\text {Brand }} \text { Brand }_{i, j}+\beta_{\text {year }} \text { EEAR }_{i}+\beta_{\text {ind }} I_{N D U S T R Y_{j}}
$$

where $M V$ is the market value of each $j$-firm $i$-year observation; $B V$ is the common equity at the end of each year; $N I$ is the net income of each $j$-firm $i$-year observation; Brand is the brand value provided by Brand Finance. All the variables are scaled to $j$-firm's number of outstanding shares (Mechelli \& Cimini, 2016) at the end of each $i$-year, since share-deflated models have been proven to better perform in terms of precision in presence of scale effects (Barth \& Clinch, 2009). We also control for Year and Industry. The statistical significance of each coefficient means that the corresponding variable is positively (or negatively) reflected into stock prices. We hypothesize that the significance of $\beta_{B r a n d}$ is different for each market, meaning that brand values have a different relevance in each country.

We consider brand values published in Brand Finance's reports since this consulting firm provides more value relevant brand values then the others (Bagna et al., 2017). The main reason could be the use by Brand Finance of comparable transactions (i.e. license agreements) to estimate the royalty rates, which gives this method a higher objectivity being it a market-income methodology (Rubio, Manuel \& Pérez-Hernàndez, 2016).

To estimate brand values published in annual reports Brand Finance employs the following formula:

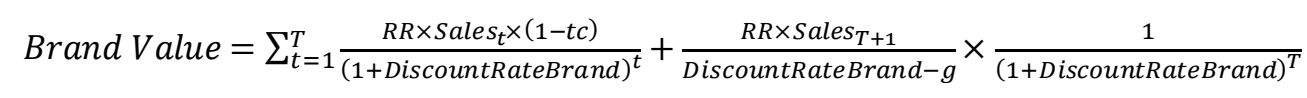

where Sales $s_{t}$ is the firm's sales, $R R$ is the royalty rate obtained from comparable license agreements, $t c$ is the tax rate, DiscountRateBrand is the opportunity cost of the brand and $g$ is the growth rate.

As shown in the above formula, Brand Finance uses the royalty relief (or relief from royalties) method, which implies that the value of an asset is given by the royalties a company should pay to detain the asset, discounted at a specific cost of capital. This method is adopted for the following reasons:

- royalty rates are obtained from comparable transactions, bringing to a more objective brand value;

- courts and tax authorities sustain the use of this method since royalty rates are documented by third parties' transactions;

- it is compliant with International Valuation Standards Authority and ISO 10668;

- it can be put in practice using public available information.

As a previous work proves that Brand Finance values are built not using market parameters we do not test for endogeneity in the regression (Bagna et al., 2017). Consequently, the statistical correlation is not caused by simultaneous bias.

\subsection{Sample Composition}

The sample consists in brand values provided by Brand Finance and published in annual reports from 2008 to 2015 (for a specification of the reports considered, see Appendix). Values for 920 brands have been collected (4,999 observations). Different brands detained by the same firm are treated as a unique brand and their values are summed for each year, reducing the observations to 2,672. Firstly, we drop brands which have been acquired 
by other companies during the time frame (2008-2015). At the stage, we count 37 different countries from all over the world. Since we regress market values over fundamentals such as net income and book value, firms with missing accounting data are excluded. Observations are then clustered depending on the country of each firm. Each country is treated as different sample and therefore sub-samples with less than 30 observations are eliminated. Overall, the final sample consists in 2,518 observations from 17 different countries (see Table 1). The sample counts 593 firms, operating in 10 different industries, which detain a total of 813 brands.

Table 1. Observations per year

\begin{tabular}{cc}
\hline Year & Obs. \\
\hline 2008 & 358 \\
2009 & 378 \\
2010 & 377 \\
2011 & 369 \\
2012 & 384 \\
2013 & 273 \\
2014 & 278 \\
2015 & 101 \\
\hline Total & $\mathbf{2 , 5 1 8}$ \\
\hline
\end{tabular}

The number of observations by year (Table 1) is constant for the first 5 years (2008-2012) but they decrease starting from 2013.This reduction is connected with the birth of new high-value brands based in countries, especially Asian, for which we do not have at least 30 observations and therefore they were excluded from our sample.

Table 2 contains the descriptive statistics of the variables of the model proposed. Market value is in mean $\$ 66.24$, ranging from $\$ 0.51$ to $\$ 1,199.66$ and revealing a high variability among companies. Common equity (per share) counts on average $\$ 40.23$, whereas net income (per share) assumes a mean value of $\$ 5.40$. Finally, the range of brand value per share varies from $\$ 0.09$ to $\$ 319.41$ with a mean of $\$ 15.90$.

Table 2. Descriptive Statistics (per share values)

\begin{tabular}{llllll}
\hline & Minimum & Maximum & Sum & Mean & Std. Deviation \\
\cline { 2 - 6 } Market Value & $\$ 0.51$ & $\$ 1,199.66$ & $\$ 166,799.19$ & $\$ 66.24$ & $\$ 149.66$ \\
Common Equity & $\$-1.47$ & $\$ 1,001.58$ & $\$ 101,308.12$ & $\$ 40.23$ & $\$ 118.34$ \\
Net Income & $\$-6.95$ & $\$ 145.65$ & $\$ 13,596.44$ & $\$ 5.40$ & $\$ 17.38$ \\
Brand Value & $\$ 0.09$ & $\$ 319.41$ & $\$ 40,034.35$ & $\$ 15.90$ & $\$ 39.03$ \\
\hline
\end{tabular}

As shown in the following tables, the biggest sub-sample is USA, which includes 978 observations, followed by Japan and France, while the smallest one is Italy with only 32 observations (Table 3).

Regarding industry composition of our sample (Table 3), we count 10 different industries. More than $22 \%$ of the observations are referred to financial firms. Consumers goods, consumer services and industrial firms represent respectively $19 \%, 18 \%$ and $11 \%$ of our sample, whereas companies belonging to basic material, healthcare, oil \& gas and utilities sectors count comprehensively only $14 \%$ of the total observations.

In terms of values per share or total values, the biggest sub-sample is still USA(Table 4 and Table 5).

Table 3. Industries per country

\begin{tabular}{|c|c|c|c|c|c|c|c|c|c|c|c|}
\hline Country & $\begin{array}{c}\text { Basic } \\
\text { Materials }\end{array}$ & $\begin{array}{l}\text { Consumer } \\
\text { Goods }\end{array}$ & $\begin{array}{l}\text { Consumer } \\
\text { Services }\end{array}$ & Financial & Health Care & Industrials & Oil \& Gas & Technology & Telecom & Utilities & Total \\
\hline Australia & 3 & 0 & 11 & 30 & 0 & 0 & 0 & 0 & 8 & 0 & 52 \\
\hline Brazil & 4 & 2 & 2 & 15 & 0 & 0 & 5 & 0 & 6 & 1 & 35 \\
\hline Canada & 0 & 0 & 4 & 46 & 0 & 8 & 0 & 7 & 14 & 0 & 79 \\
\hline China & 1 & 22 & 18 & 67 & 0 & 12 & 15 & 13 & 22 & 0 & 170 \\
\hline France & 0 & 53 & 40 & 31 & 3 & 25 & 8 & 7 & 8 & 15 & 190 \\
\hline Germany & 8 & 58 & 17 & 27 & 3 & 21 & 0 & 7 & 2 & 13 & 156 \\
\hline India & 0 & 0 & 0 & 9 & 0 & 9 & 11 & 15 & 4 & 0 & 48 \\
\hline Italy & 0 & 10 & 0 & 8 & 0 & 0 & 4 & 0 & 5 & 5 & 32 \\
\hline Japan & 5 & 115 & 32 & 31 & 3 & 48 & 1 & 32 & 27 & 16 & 310 \\
\hline Korea & 4 & 16 & 2 & 10 & 0 & 0 & 0 & 2 & 7 & 5 & 46 \\
\hline Netherlands & 5 & 10 & 1 & 15 & 7 & 4 & 8 & 0 & 3 & 0 & 53 \\
\hline Russia & 1 & 0 & 6 & 7 & 0 & 0 & 14 & 0 & 6 & 0 & 34 \\
\hline Spain & 0 & 0 & 8 & 20 & 0 & 8 & 0 & 0 & 7 & 11 & 54 \\
\hline Sweden & 0 & 1 & 8 & 8 & 0 & 10 & 0 & 7 & 5 & 0 & 39 \\
\hline Switzerland & 1 & 15 & 0 & 28 & 7 & 16 & 0 & 0 & 5 & 0 & 72 \\
\hline UK & 6 & 19 & 49 & 52 & 5 & 4 & 8 & 0 & 16 & 11 & 170 \\
\hline USA & 8 & 154 & 267 & 169 & 66 & 123 & 30 & 123 & 21 & 17 & 978 \\
\hline Total & 46 & 475 & 465 & 573 & 94 & 288 & 104 & 213 & 166 & 94 & 2518 \\
\hline
\end{tabular}


Table 4. Descriptive statistics at country level (per share values)

\begin{tabular}{|c|c|c|c|c|c|}
\hline \multicolumn{2}{|c|}{ Country } & MV & Common Equity & Net Income & Brand Value \\
\hline & Mean & Mean & Mean & Mean \\
\hline & $\$ 26.78$ & $\$ 18.91$ & $\$ 2.43$ & $\$ 2.56$ \\
\hline \multicolumn{2}{|l|}{ Brazil } & $\$ 17.46$ & $\$ 21.40$ & $\$ 2.79$ & $\$ 8.93$ \\
\hline \multicolumn{2}{|l|}{ Canada } & $\$ 44.70$ & $\$ 23.48$ & $\$ 3.44$ & $\$ 6.44$ \\
\hline \multicolumn{2}{|l|}{ China } & $\$ 9.08$ & $\$ 4.07$ & $\$ 0.68$ & $\$ 2.65$ \\
\hline \multicolumn{2}{|l|}{ France } & $\$ 62.50$ & $\$ 41.27$ & $\$ 3.44$ & $\$ 15.21$ \\
\hline \multicolumn{2}{|l|}{ Germany } & $\$ 113.32$ & $\$ 114.22$ & $\$ 14.49$ & $\$ 35.22$ \\
\hline \multicolumn{2}{|l|}{ India } & $\$ 21.90$ & $\$ 7.69$ & $\$ 1.38$ & $\$ 4.75$ \\
\hline \multicolumn{2}{|l|}{ Italy } & $\$ 8.95$ & $\$ 9.36$ & $\$ 0.49$ & $\$ 3.91$ \\
\hline \multicolumn{2}{|l|}{ Japan } & $\$ 94.27$ & $\$ 75.30$ & $\$ 9.03$ & $\$ 23.55$ \\
\hline \multicolumn{2}{|l|}{ Korea } & $\$ 255.72$ & $\$ 192.60$ & $\$ 25.37$ & $\$ 64.67$ \\
\hline \multicolumn{2}{|l|}{ Netherlands } & $\$ 26.25$ & $\$ 22.03$ & $\$ 1.89$ & $\$ 10.09$ \\
\hline \multicolumn{2}{|l|}{ Russia } & $\$ 36.83$ & $\$ 16.46$ & $\$ 3.05$ & $\$ 6.39$ \\
\hline \multicolumn{2}{|l|}{ Spain } & $\$ 24.05$ & $\$ 10.46$ & $\$ 1.78$ & $\$ 3.73$ \\
\hline \multicolumn{2}{|l|}{ Sweden } & $\$ 16.44$ & $\$ 6.54$ & $\$ 0.94$ & $\$ 3.16$ \\
\hline \multicolumn{2}{|l|}{ Switzerland } & $\$ 129.24$ & $\$ 75.21$ & $\$ 10.22$ & $\$ 25.73$ \\
\hline \multicolumn{2}{|c|}{ United Kingdom } & $\$ 11.73$ & $\$ 5.07$ & $\$ 0.86$ & $\$ 2.15$ \\
\hline \multicolumn{2}{|c|}{ USA } & $\$ 73.58$ & $\$ 30.34$ & $\$ 4.91$ & $\$ 16.69$ \\
\hline \multicolumn{6}{|c|}{ Table 5. Descriptive statistics at country level (total per share values) } \\
\hline Country & Obs. & $\%$ of total sample & $\begin{array}{c}\text { Total } \\
\text { B rand Value }\end{array}$ & $\begin{array}{c}\text { Total } \\
\text { Market value }\end{array}$ & $\begin{array}{c}\text { Total } \\
\text { Common equity }\end{array}$ \\
\hline Australia & 52 & $2.1 \%$ & $\$ 247,234$ & $\$ 2,706,080$ & $\$ 1,436,070$ \\
\hline Brazil & 35 & $1.4 \%$ & $\$ 232,362$ & $\$ 1,305,378$ & $\$ 1,425,814$ \\
\hline Canada & 79 & $3.1 \%$ & $\$ 337,737$ & $\$ 2,761,560$ & $\$ 1,456,788$ \\
\hline China & 170 & $6.8 \%$ & $\$ 1,487,319$ & $\$ 8,502,102$ & $\$ 8,896,985$ \\
\hline France & 190 & $7.5 \%$ & $\$ 1,392,151$ & $\$ 6,718,483$ & $\$ 5,279,659$ \\
\hline Germany & 156 & $6.2 \%$ & $\$ 1,442,968$ & $\$ 5,688,939$ & $\$ 4,467,192$ \\
\hline India & 48 & $1.9 \%$ & $\$ 268,692$ & $\$ 1,273,166$ & $\$ 461,415$ \\
\hline Italy & 32 & $1.3 \%$ & $\$ 262,280$ & $\$ 1,076,024$ & $\$ 1,396,820$ \\
\hline Japan & 310 & $1.3 \%$ & $\$ 2,230,915$ & $\$ 8,469,801$ & $\$ 7,093,548$ \\
\hline Korea & 46 & $1.8 \%$ & $\$ 543,214$ & $\$ 1,808,288$ & $\$ 1,547,412$ \\
\hline Netherlands & 53 & $2.1 \%$ & $\$ 470,181$ & $\$ 2,082,604$ & $\$ 2,430,501$ \\
\hline Russia & 34 & $1.4 \%$ & $\$ 131,169$ & $\$ 1,659,110$ & $\$ 1,826,905$ \\
\hline Spain & 54 & $2.1 \%$ & $\$ 435,603$ & $\$ 2,513,005$ & $\$ 1,665,737$ \\
\hline Sweden & 39 & $1.5 \%$ & $\$ 202,661$ & $\$ 1,139,545$ & $\$ 563,321$ \\
\hline Switzerland & 72 & $2.9 \%$ & $\$ 545,847$ & $\$ 4,047,327$ & $\$ 1,841,006$ \\
\hline United Kingdom & 170 & $6.8 \%$ & $\$ 1,387,061$ & $\$ 7,831,528$ & $\$ 5,839,389$ \\
\hline USA & 978 & $38.8 \%$ & $\$ 14,278,904$ & $\$ 59,939,107$ & $\$ 26323,706$ \\
\hline Total & 2,518 & $100,0 \%$ & $\$ 25,896,298$ & $\$ 119,522,047$ & $\$ 73,952,266$ \\
\hline
\end{tabular}

\section{Results \& Discussion}

Results are reported in Table 6. As before explained, we run separated OLS regression for each of the 17 subsamples (i.e. country). Even if adjusted $\mathrm{R}^{2}$ are higher than $87 \%$ in median, showing that the model is fitting good, we find statistically insignificant brand coefficients for Australia, Brazil, India, South Korea and Netherlands, meaning that this kind of information has no informative content for investors in those countries. In particular, for Australia this could be explained by the fact that Australian GAAPs allow to report internally generated intangible assets, such as brands. Consequently, investors already appreciate the brand value recognized in the balance sheet.

Italian brand coefficient is statistically significant and its negative value can be explained by the particular sample composition: actually, most of the firms are considered to have Business-to-Business activity. This characteristic produces a lower value relevance for brand values, as demonstrated by Kirk et al. (2013).

The hypothesis of our research is thus confirmed, since we find a different, and sometimes null, value relevance of brand values in different countries. However, further analyses would be needed to test why brand values are not value relevant in Brazil, India, South Korea and Netherlands. 
Table 6. Multivariate analysis results by sub-sample

\begin{tabular}{|c|c|c|c|c|c|}
\hline Country & $\mathbf{R 2}$ & Adjusted R2 & Obs. & Brand Coefficient & Brand Significance \\
\hline Australia & 0.873 & 0.830 & 52 & 0.3097 & 0.795 \\
\hline Brazil & 0.771 & 0.630 & 35 & -0.2083 & 0.108 \\
\hline Canada & 0.689 & 0.621 & 79 & 2.3166 & $* * 0.016$ \\
\hline China & 0.761 & 0.734 & 170 & 0.4271 & $* * 0.013$ \\
\hline France & 0.626 & 0.586 & 190 & 2.1244 & $* * * 0.000$ \\
\hline Germany & 0.929 & 0.920 & 156 & 1.5239 & $* * * 0.000$ \\
\hline India & 0.792 & 0.704 & 48 & 0.7241 & 0.180 \\
\hline Italy & 0.878 & 0.789 & 32 & -1.2155 & $* * * 0.001$ \\
\hline Japan & 0.988 & 0.987 & 310 & 1.3121 & $* * * 0.000$ \\
\hline South Korea & 0.971 & 0.955 & 46 & -1.1644 & 0.290 \\
\hline Netherlands & 0.927 & 0.891 & 53 & -0.0974 & 0.232 \\
\hline Russia & 0.982 & 0.970 & 34 & 1.8666 & $* * * 0.001$ \\
\hline Spain & 0.791 & 0.716 & 54 & 2.7639 & $* 0.054$ \\
\hline Sweden & 0.963 & 0.939 & 39 & 1.4046 & $* 0.071$ \\
\hline Switzerland & 0.956 & 0.944 & 72 & 1.0560 & $* * * 0.001$ \\
\hline$U K$ & 0.783 & 0.757 & 170 & 1.7913 & $* * * 0.000$ \\
\hline USA & 0.731 & 0.725 & 978 & 1.7213 & $* * * 0.000$ \\
\hline
\end{tabular}

\section{Conclusions}

Prior literature provides many evidences that the value relevance of accounting data differs across countries and it is affected by the institutional context and environmental characteristics. No previous study examines the cross-country value relevance of brand values provided by third-independent parties. Since almost all the accounting standards reject the recognition of internally generated intangible assets, investors often use information provided by third-independent parties, such as brand values. The aim of this study is to test whether the value relevance of brand values differs across countries. We selected a sample of brand values provided by Brand Finance from 2008 to 2015 owned by firms settled in 17 different countries. To verify our hypothesis, we run the traditional value relevance regression model in order to test the differences in the value relevance of brand values across countries. The model is proven to be unaffected by endogeneity bias, therefore brand values coefficients explain how these values are incorporated into stock prices. This result is a first insight about how market participants appraise this specific data. All subsamples have been analyzed equally and $\mathrm{R}^{2}$ values (above $60 \%$ ) indicate that the model is "well fitting". Results show that brand values: i) are differently reflected in each country and ii) are not value relevant in some cases, in particular in Australia, Brazil, India, South Korea and Netherlands. Since investment choices need to be supported by different information, investors and practitioners should keep in mind which information is reflected into stock prices and how. Considering that brand values are proven to be value relevant by previous literature and that cross-country value relevance of accounting data has been already investigated, this contribution could improve the use of brand related information in capital allocation choices. Also, this practical implication is particularly important for cross country and foreign investments, seeing that each market reflects brand values differently due to the influence of country-specific factors. Even if findings are promising, this paper represents a first step to test whether information relevance is affected by environmental characteristics and institutional context. Certainly, these factors are able to influence the informative process of investors and therefore they need to be further investigated.

Our study is affected by different limitations. Firstly, countries sub-sample are heterogeneous in dimension and in composition. Secondly, we do not identify which factors affect the informative content of brand values. Future research should be focused in this direction. However, our results are consistent with previous studies and this exploratory work offers evidence on the existence of different informative content of third parties brand values across countries.

\section{References}

Aaker, D. A., \& Jacobson, R. (2001). The Value Relevance of Brand Attitude in High-Technology Markets. Journal of Marketing Research, 38(4), 485-493. https://doi.org/10.1509/jmkr.38.4.485.18905

Alford, A., Jones, J., Leftwich, R., \& Zmijewski, M. (1993). The Relative Informativeness of Accounting Disclosures in Different Countries. Journal of Accounting Research, 31, Studies on International Accounting, 183-223. https://doi.org/10.2307/2491170

Ali, A., \& Hwang, L. (2000). Country-specific factors related to financial reporting and the value relevance of accounting data. Journal of Accounting Research, 38(1), 1-21. https://doi.org/10.2307/2672920

Arce, M., \& Mora, A. (2002). Empirical evidence of the effect of European accounting differences on the stock 
market valuation of earnings and book value. European Accounting Review, 11(3), 573-599. https://doi.org/10.1080/09638180220125616

Bagna, E., Dicuonzo, G., Perrone, A., Dell'Atti, V. (2017). The value relevance of brand valuation. Applied Economics, 49(58), 5865-5876. https://doi.org/10.1080/00036846.2017.1352078

Barth, M. E., \& Clinch, G. (1998). Revalued Financial, Tangible, and Intangible Assets: Associations with Share Prices and Non-Market-Based Value Estimates. Journal of Accounting Research, 36, Studies on Enhancing the Financial Reporting Model, 199-233. https://doi.org/10.2307/2491314

Barth, M. E., \& Clinch, G. (2009). Scale effects in capital markets-based accounting research. Journal of Business Finance \& Accounting, 36(3-4), 253-288. https://doi.org/10.1111/j.1468-5957.2009.02133.x

Barth, M. E., Clement, M. B., Foster, G., Kasznik, R. (1998). Brand Values and Capital Market Valuation. Review of Accounting Studies, 3, 41-68. https://doi.org/10.1023/A:1009620132177

Beretta, Z. A., \& Vernizzi, S. (2014). Goodwill Reduction: The Competitive Analysis of Enterprise Value (A Note). International Business Research, 7(11), 35-50. https://doi.org/10.5539/ibr.v7n11p35

Brown, W. D., He, H., \& Teitel, K. (2006). Conditional Conservatism and the Value Relevance of Accounting Earnings: An International Study. European Accounting Review, 15(4), 605-626. https://doi.org/10.1080/09638180601102198

Camodeca, R., Almici, A., \& Renzi, B. A. (2014). The value relevance of accounting information in the Italian and UK stock markets. Problems and Perspectives in Management, 12(4), 512-519.

Hellström, K. (2006). The Value Relevance of Financial Accounting Information in a Transition Economy: The Case of the Czech Republic. European Accounting Review, 15(3), 325-349. https://doi.org/10.1080/09638180600916242

Kallapur, S., \& Kwan, S. (2004). The Value Relevance and Reliability of Brand Assets Recognized by UK Firms, Purdue CIBER Working Papers, Paper 18.

Kerin, R. A., \& Sethuraman, R. (1998). Exploring the brand value-shareholder value nexus for consumer goods companies. Journal of the Academy of Marketing Science, 26(4), 260-273. https://doi.org/10.1177/0092070398264001

Kirk, C. P., Ray, I., \& Wilson, B. (2013). The impact of brand value on firm valuation: the moderating influence of firm type. Journal of Brand Management, 20(6), 488-500. https://doi.org/10.1057/bm.2012.55

La Porta, R., Lopez-De-Silanes, F., Shleifer, A., \& Vishny R. W. (1997). Legal Determinants of External Finance. The Journal of Finance, 52(3), 1131-1150. https://doi.org/10.1111/j.1540-6261.1997.tb02727.x

Madden, T. J., Fehle, F., Fournier S. (2006). Brands matter: an empirical demonstration of the creation of shareholder value through branding. Journal of the Academy of Marketing Science, 34(2), 224-235. https://doi.org/10.1177/0092070305283356

Mechelli, A., \& Cimini, R., (2017). Do (Audit Firm and Key Audit Partner) Rotations Affect Value Relevance? Empirical Evidence from the Italian Context. International Business Research, 10(1), 143-152. https://doi.org/10.5539/ibr.v10n1p143

Mizik, N., \& Jacobson, R. (2008). The Financial Value Impact of Perceptual Brand Attributes. Journal of Marketing Research, 45, 15-32. https://doi.org/10.1509/jmkr.45.1.15

Ohlson, J. A., (1995). Earnings, book values, and dividends in equity valuation. Contemporary Accounting Research, 11(2), 661-687. https://doi.org/10.1111/j.1911-3846.1995.tb00461.x

Rubio, G., Manuel, C. M., \& Pérez-Hernàndez F. (2016). Valuing brands under royalty relief methodology according to international accounting and valuation standards. European Journal of Management and Business Economics, 25, 76-87. https://doi.org/10.1016/j.redeen.2016.03.001 
Appendix: List of Brand Finance reports

\begin{tabular}{cc}
\hline Report Name & Year \\
\hline Global 500 & 2008 \\
Global 500 & 2009 \\
Global 500 & 2010 \\
Global 500 & 2011 \\
Global 500 & 2012 \\
Global 500 & 2014 \\
Global 500 & 2015 \\
Global 500 & 2016 \\
Airlines 50 & 2015 \\
Auto 100 & 2015 \\
Banking 500 & 2015 \\
Drinks 50 & 2015 \\
Fast food 10 & 2015 \\
Food 25 & 2015 \\
Insurance 50 & 2015 \\
Oil \& Gas 50 & 2015 \\
Pharma 10 & 2015 \\
Retail 50 & 2015 \\
Soft Drinks 10 & 2015 \\
Tech 100 & 2015 \\
Telecoms 500 & 2015 \\
Tobacco 10 & 2015 \\
Utilities 15 & 2015 \\
Spirits 50 & 2016 \\
\hline
\end{tabular}

\section{Copyrights}

Copyright for this article is retained by the author(s), with first publication rights granted to the journal.

This is an open-access article distributed under the terms and conditions of the Creative Commons Attribution license (http://creativecommons.org/licenses/by/4.0/). 